\title{
The ragged edge
}

\author{
Reflections upon what is to be found in books, besides the text.
}

DR JOHNSON said about cucumbers that they should be well sliced, and dressed with pepper and vinegar, and then thrown out as good for nothing. This is more or less what happens when scientific information of similar insipidity is processed into books, that are catalogued and at once fade, all but a few of them, from human consciousness. To browse among the review copies that each week fill some yards of shelf space in offices of journals such as this quickly induces a desolating sense of the futility of man's endeavour. Who will actually read this tome containing the Proceedings of the Fifth Annual Conference on Isoelectric Focussing in Polyacrylamide Gels? Will the narrative perhaps go with more of a swing than the sinking feeling in one's viscera portends? It will not. It will be what Lewis Carroll subtitled The Hunting of the Snark - an agony in five fits. Why do they do it then, those battalions of authors and editors? I think it was a historian who defined research as reading two books that have never before been read in order to write a thesis that will also never be read. Perhaps Byron hit the nail on the head:

'Tis pleasant, sure, to see one's name in print; $A$ book's a book, although there's nothing in't.

There is material here from which more than one PhD thesis could be hewn. If there is little pleasure or improvement to be had from the texts of most books, can we find it elsewhere between the covers? There is not much fun in the index, the contribution all too often, it seems, of the author's wife. The best one can hope for is a diverting typo or two: what for instance are these congenial metabolic diseases to which this one keeps referring? And what are the particular virtues of freeze-frying? But no, there are more abundant pickings for the sociologist of science nearer the title page. The dust-flap of course often yields a morsel for the connoisseur. Here is one that comes to me at second-hand, by way of the New Yorker; it commends the book, a dictionary, gift bound in tooled cowhide, and notes that it is "alphabetized for easy reference". Good idea, comments the New Yorker. But it is more likely that you will merely be assured that you hold in your hand an integrated wide-parameter, indepth state-of-the-art overview, that will enable the student to digest this seminal cornerstone of a rich and pregnant field; it will set new benchmark standards as a very nearly unique quantum jump, an indispensable framework, comprehensive yet concise, directed as much at the specialist research worker as at the undergraduate, and essential reading for astronomers, cytologists, palaeontologists, cytopalaeoastronomers, palaeocytologists and astro- palaeontologists. But since the credit for such gems of the blurb-writer's craft cannot be laid on the author, let us start at the beginning with the epigraph. This may be in Latin or even Greek (in which the author does not have to be fluent), but if in English it should preferably be totally inscrutable. Thus: "A philosopher does not need a torch to gather glow-worms by at mid-day" - Ernest Bramah.

There follows the preface with a list of acknowledgements in which wives and family feature by reason of their fortitude in sharing for several weeks the ardours of a scribe's life. More particularly, wives without exception have typed the manuscript, compiled the index, read the proofs or supplied candid and perceptive criticism. How many such wives are wives still by the time the book is in print? The late Queenie Leavis was said to have discovered only on publication that she was not co-author of one of her husband's blockbusters. There has been a rash of lawsuits in recent years, from which emerged sorry stories of helpmeets, who not only filled fountain-pens, typed manuscripts and cooked meals, but also earned money to see the husband through his $\mathrm{PhD}$ and were then returned to store for their pains. The scientific wife is a social species ripe for a $\mathrm{PhD}$ of her own.

It is customary for the author also to render thanks to a colleague or two for critical reading of the text; it would be an almost indecent breach of tradition not to conclude with the arch avowal that what errors remain are his - but the implication is that they are his friends' just the same. (As Charles II said in response to Rochester's famous mock-epitaph, " $\mathrm{He}$ never said a foolish thing/Nor ever did a wise one" - his words were his own, but his deeds were his ministers). There is then much citing of sources from which material has been gouged. I have only once seen a trickle of bile, such as many authors must have suppressed with difficulty; it comes from Jonathan Gathorne-Hardy's splendid treatise on the British nanny: "I must also formally acknowledge the following publishers, institutions and people for their permission, often after substantial payment, to quote from the books whose copyright they control...". The sycophantic expressions of gratitude to patrons have alas largely vanished, for the realization has grown that institutions, even those as munificent as the National Institutes of Health, have no mechanism for receiving homage or converting it into gratification. To thank the NIH has always seemed to me a little like the action of the small boy who was observed by the Reverend Sydney Smith to be stroking the shell of a tortoise () 1985 Nature Publishing Group in order, as he said, to please the creature; "why", said Sydney Smith, "you might as well stroke the dome of St. Paul's to please the Dean and Chapter'. More entertainment was to be had from writers' relations with patrons of an earlier age. $\mathrm{Dr}$ Johnson's dissatisfaction with Lord Chesterfield's performance in the office is recorded in the Dictionary, in which he defines a patron as "one who countenances, supports or protects. Commonly a wretch who supports with insolence, and is paid with flattery". He enlarged on this in his celebrated letter to Chesterfield, in which he drew the parallel between the patron and one who observes the struggles of a drowning man and only when he reaches the shore encumbers him with help. Analogies in the support of modern science suggest themselves.

Not the least of the author's problems is the dedication. A spouse, mistress or auntie can at least be relied nn to accept. (I have even seen, indeed cc ntributed to, a multi-author volume in which the editors dedicated their collection of other men's flowers to their wife.) The most embarrassing of undesired and undesirable favours is the Festschrift. Some years ago an aging and eminent physicist, sensible of the approaching danger, declared in an article with the title of "Fest me no Schriften" that he did not wish to become a pretext for the unloading of unrefereed and possibly otherwise unpublishable contributions by his former students and colleagues (whom he probably did not like anyway). The Duke of Wellington once declined a dedication, explaining that he had been obliged to make a rule to do so "because, in his situation as Chancellor of the University of Oxford, he had been much exposed to authors".

As to the foreword, its object is to praise the book, and a hypocritical show of modesty can be avoided if the services of an elder of the subject can be secured. The leaden phrases that fall so easily from the pens of such illuminati are all too familiar. An ingenious ploy was contrived by Newton, who when President of the Royal Society set up a hand-picked committee to prepare a report on the rival claims of Leibniz and himself to the calculus, and then himself wrote an anonymous and fulsome foreword, commending the conclusions. But let us end with a more wholesome example, that of Boswell, who had no need of specious humility in launching his Life of Johnson. In what he candidly termed the "Advertisement" to the first edition, he begins: "I at last deliver to the world a work which I have long promised" and concludes, "nor will I suppress my satisfaction in the consciousness, that by recording so considerable a portion of the wisdom and wit of 'the brightest ornament of the eighteenth century', I have largely provided for the instruction and entertainment of mankind"'. But then his subject was better than the oxides and oxyacids of sulphur. 